\title{
Influence of dietary protein and fat on serum lipids and metabolism of essential fatty acids in rats
}

\author{
BY W. M. NIMAL RATNAYAKE ${ }^{1}$, GHULAM SARWAR ${ }^{1}$ AND PATRICK LAFFEY $^{2}$ \\ ${ }^{1}$ Nutrition Research Division, Bureau of Nutritional Sciences, and ${ }^{2}$ Bureau of Biostatistics and \\ Computer Applications, Food Directorate, Health Protection Branch, Health Canada, Ottawa, Ontario, \\ Canada KIA OL2
}

(Received 23 September 1996-Revised 12 February 1997-Accepted 5 March 1997)

\begin{abstract}
A $120 \mathrm{~d}$ feeding study with adult rats was conducted to evaluate the influence of two protein sources (casein and gelatin), two protein levels $(50$ and $300 \mathrm{~g} / \mathrm{kg}$ diet) and two fat levels (50 and $150 \mathrm{~g} / \mathrm{kg}$ diet) on serum lipids (total cholesterol, HDL-cholesterol and triacylglycerols) and liver polyunsaturated fatty acid levels. In general, the concentrations of serum triacylglycerols and total cholesterol and liver phospholipid levels of arachidonic acid (AA) and docosahexaenoic acid (DHA) were higher in rats fed on casein diets compared with those fed on the gelatin diets. These effects were more pronounced in rats fed on the high-casein $(300 \mathrm{~g} / \mathrm{kg})-$ high-fat $(150 \mathrm{~g} / \mathrm{kg})$ diet. Gelatin was hypocholesterolaemic and also suppressed the liver phospholipid levels of AA and DHA (reported for the first time). The difference in the amino acid composition between casein and gelatin may be responsible for the observed effects. Casein contains higher levels of glutamic acid, methionine, phenylalanine and tyrosine, while gelatin contains higher levels of arginine, glycine and hydroxyproline. It is suggested that a protein source which increases serum cholesterol may also increase the concentrations of $\mathrm{AA}$ and DHA in rat tissues.
\end{abstract}

Casein: Gelatin: Essential fatty acids

Dietary protein is known to influence cholesterol metabolism (Carroll \& Kurowska, 1995; Kritchevsky, 1995). Protein of animal origin, such as casein, is more cholesterolaemic and atherogenic than plant protein, such as soyabean protein, in human subjects and a variety of animal models (Erdman \& Fordyce, 1989; Carroll, 1991). Casein may exert its hypercholesterolaemic effect by mechanisms which include increased absorption and decreased turnover of cholesterol (Kritchevsky, 1995). The addition of single amino acids to casein has been reported to influence cholesterolaemia (Sugiyama \& Muramatsu, 1990). In rats fed on cholesterol-free diets containing different protein sources, positive correlations between serum cholesterol and dietary glutamic acid, methionine, proline or tyrosine; and negative correlations between serum cholesterol and dietary alanine, arginine or cystine have been reported (Sautier et al. 1983, 1986). Information on the comparative effects of purified animal protein sources with markedly different amino acid compositions is, however, limited.

The activity of desaturases catalysing the biosynthesis of essential fatty acid metabolites such as arachidonic acid (AA) and docosahexaenoic acid (DHA) was also reported to be influenced by the quantity and quality of dietary protein (Inkpen et al. 1969; Peluffo et al. 1971, 1984). Consequently dietary protein influences the levels of AA, DHA and other long-chain $n-6$ and $n-3$ polyunsaturated fatty acids (PUFA) in rat tissues. A highprotein diet containing $45 \%$ energy from casein increased $\Delta 6$ desaturase activity in rat 
liver microsomes compared with a low-protein diet supplying $5 \%$ energy from casein (Peluffo et al. 1984), suggesting that protein-deficient children may develop a notable deficiency of essential fatty acids (Brenner, 1981). High-protein diets containing $45 \%$ energy from a mixture of crystalline amino acids (simulating the amino acid composition of casein) also increased the activity of $\Delta 6$ desaturase in rat liver microsomes but decreased the activity of $\Delta 9$ desaturase compared with a high-sucrose diet (Peluffo et al. 1984). The elimination of phenylalanine and tyrosine from the amino acid mixture increased the $\Delta 6$ desaturase activity and massive amounts $(200 \mathrm{~g} / \mathrm{kg})$ of phenylalanine or tyrosine in the diet inhibited $\Delta 6$ desaturase activity.

The studies by Peluffo et al. $(1971,1984)$ on the effects of the quantity of protein and the type of amino acids on the activity of desaturases in rat liver microsomes, were conducted with growing rats. Since the low-protein diet and the amino-acid-mixture diet devoid of phenylalanine, tyrosine and/or tryptophan did not meet the essential amino acid requirements for rat growth, the validity of these studies may be limited. Moreover, the addition of large amounts $(200 \mathrm{~g} / \mathrm{kg})$ of phenylalanine or tyrosine in the study by Peluffo $e t$ al. (1984) may have created an amino acid imbalance.

It was, therefore, of interest to obtain further information on the influence of the quantity and quality of dietary protein on the levels of serum lipids and of PUFA in rat livers using a nutritionally balanced experimental design. A $120 \mathrm{~d}$ feeding study with adult rats was conducted to study the influence of two highly digestible animal protein sources with markedly different protein quality (casein and gelatin), two protein levels (50 and $300 \mathrm{~g} / \mathrm{kg} \mathrm{diet}$ ) and two fat levels (50 and $150 \mathrm{~g} / \mathrm{kg}$ diet) on serum lipids (total cholesterol, HDL-cholesterol and triacylglycerols) and liver PUFA levels after $30 \mathrm{~d}$ and $120 \mathrm{~d}$ of the study.

\section{METHODS}

\section{Diets}

The compositions of the eight experimental diets (high casein-low fat, HCLF; high caseinhigh fat, HCHF; low casein-low fat, LCLF; low casein-high fat, LCHF; high gelatin-low fat, HGLF; high gelatin-high fat, HGHF; low gelatin-low fat LGLF; low gelatin-high fat, LGHF) are shown in Tables 1 and 2 . The diets were prepared weekly and stored at $-4^{\circ}$. The low-protein casein diets and gelatin diets were supplemented with small amounts of limiting crystalline amino acids (Sigma Chemical, St. Louis, MO, USA) to ensure that experimental diets met the indispensable amino acid requirement for rat maintenance (National Research Council, 1978). Within each protein level $(50$ or $300 \mathrm{~g} / \mathrm{kg})$, diets were made isonitrogenous by the addition of L-glutamic acid and/or glycine. All the experimental diets also met the essential fatty acid requirements for rat maintenance (National Research Council, 1978).

The metabolizable energy (ME) per $\mathrm{kg}$ diet of the four low-fat diets (HCLF, LCLF, HGLF and LGLF) was 14.49 MJ and that of the four high-fat diets (HCHF, LCHF, HGHF and LGHF) was 16.58 MJ. ME was calculated using the Atwater factors of 17, 37 and $17 \mathrm{~kJ} / \mathrm{g}$ for protein, fat and available carbohydrates respectively. The two dietary protein levels (50 and $300 \mathrm{~g} / \mathrm{kg}$ diet) provided 5.1-5.9 and 30.7-35.0\% energy from protein respectively. The two dietary fat levels (50 and $150 \mathrm{~g} / \mathrm{kg}$ diet) provided 12.8 and $33.5 \%$ energy from fat respectively. 
Table 1. Composition of experimental diets $(\mathrm{g} / \mathrm{kg})$

\begin{tabular}{lccrccc}
\hline \hline Diet* & Casein & Gelatin & Lard & $\begin{array}{c}\text { Rapeseed } \\
\text { oil }\end{array}$ & Sucrose & Maize starch \\
\hline HCLF & 333.3 & - & 45.0 & 5.0 & 345.8 & 172.9 \\
HCHF & 333.3 & - & 135.0 & 15.0 & 279.1 & 139.6 \\
LCLF & 55.6 & - & 45.0 & 5.0 & 526.6 & 263.5 \\
LCHF & 55.6 & - & 135.0 & 15.0 & 524.2 & 262.1 \\
HGLF & - & $306 \cdot 1$ & 45.0 & 5.0 & 364.3 & 182.1 \\
HGHF & - & 306.1 & 135.0 & 15.0 & 297.3 & 148.6 \\
LGLF & - & 51.1 & 45.0 & 5.0 & 531.5 & 265.7 \\
LGHF & - & 51.1 & 135.0 & 15.0 & 459.0 & 229.5 \\
\hline \hline
\end{tabular}

$\mathrm{H}$, high; L, low; C, casein; G, gelatin; F, fat.

* Each diet also contained $(\mathrm{g} / \mathrm{kg}$ ): AIN-76 mineral mixture (American Institute of Nutrition, 1977) 35, AIN-76A vitamin mixture (American Institute of Nutrition, 1980) 10, choline bitartrate (Sigma Chemical, St. Louis, MO, USA) 2 and cellulose (Alphacel, Teklad Test Diets, Madison, WI, USA) 50.

$\dagger$ Diets were supplemented as follows, to make the diets isonitrogenous (within each protein level) and to meet the indispensable amino acid requirements for rat maintenance: $\mathrm{HCLF}(\mathrm{g} / \mathrm{kg}): \mathrm{L}-\mathrm{Glu} 0.5 ; \mathrm{HCHF}(\mathrm{g} / \mathrm{kg}): \mathrm{L}-\mathrm{Glu} 0.5$ and Gly $0.5 ;$ LCLF $(\mathrm{g} / \mathrm{kg})$ : L-Ile 0.3, L-Met 1.0, L-Glu 3.9 and Gly $3 \cdot 2 ;$ LCHF $(\mathrm{g} / \mathrm{kg})$ : L-Ile $0 \cdot 8$, L-Met $1 \cdot 1$, L-Glu $4 \cdot 1$ and Gly 4.0; HGLF (g/kg): L-Trp 0.5; HGHF (g/kg): L-Ile 0.3, L-Met 0.2, L-Trp 0.5; LGLF (g/kg): L-His 0.4, L-Ile 2.3, L-Leu 0.4, L-Met 2.0, L-Thr 0.9, L-Trp 0.5, L-Tyr 0.6 and L-Val 1.3; LGHF (g/kg): L-His 0.5, L-Ile 2.5, L-Leu $0 \cdot 6$, L-Met 2.2, L-Thr 1.20, L-Trp 0.6, L-Tyr 0.80 and L-Val 1.6.

\section{Animals and feeding study}

Male Sprague-Dawley rats, 14 weeks old, (Charles River, Canada Inc., St. Constant, Quebec, Canada) were housed individually in metal cages in an air-conditioned room maintained at $22^{\circ}$ and $60 \%$ relative humidity with a $12 \mathrm{~h}$ day- $12 \mathrm{~h}$ night cycle. The rats were randomly assigned to eight dietary groups of ten rats per group. Food and water were available to the animals ad libitum. After an overnight fast, five rats from each group were killed and blood was collected from the aorta. Liver was frozen in liquid $\mathrm{N}_{2}$ and stored at $-80^{\circ}$ under $\mathrm{N}_{2}$ until analysed for phospholipid fatty acid composition. Blood samples

Table 2. Dietary indispensable amino acids, arginine, glycine and glutamic acid ( $\mathrm{mg} / \mathrm{MJ}$ metabolizable energy (ME)) provided by experimental diets $* \dagger$

\begin{tabular}{lrrrrrrrrrr}
\hline Diet & His & \multicolumn{1}{c}{ Ile } & Leu & Lys & Met + Cys & Phe & Phe + Tyr & Thr & Trp & Val \\
\hline HCLF & 614 & 1108 & 2103 & 1747 & 722 & 1133 & 2383 & 961 & 270 & 1417 \\
HCHF & 537 & 975 & 1837 & 1527 & 631 & 989 & 2082 & 839 & 237 & 1240 \\
LCLF & 102 & 208 & 351 & 289 & 189 & 189 & 397 & 160 & 45 & 237 \\
LCHF & 88 & 213 & 306 & 253 & 165 & 165 & 347 & 139 & 38 & 206 \\
HGLF & 164 & 287 & 573 & 801 & 217 & 423 & 494 & 342 & 48 & 413 \\
HGHF & 143 & 270 & 502 & 700 & 201 & 368 & 432 & 299 & 38 & 360 \\
LGLF & 55 & 208 & 122 & 134 & 174 & 69 & 126 & 122 & 36 & 158 \\
LGHF & 54 & 208 & 120 & 117 & 165 & 62 & 122 & 124 & 38 & 158 \\
\hline \hline
\end{tabular}

H, high; L, low; C, casein; G, gelatin; F, fat.

* Each diet met or exceeded the indispensable amino acid requirements for rat maintenance. The arginine, glycine and glutamic acid contents (mg/MJ ME) of the diets were: HCLF 768, 414, 4970; HCHF 671, 362, 4343; LCLF 128, 69, 828; LCHF 112, 60, 828; HGLF 1824, 5147, 1337; HGHF 1594, 4498, 1169; LGLF 304, 858, 223; LGHF 266, $750,195$.

† The indispensable amino acid requirements (mg/MJ ME) for rat maintenance were: His 53, Ile 206, Leu 120, Lys 72, Met + Cys 153, Phe + Tyr 120, Thr 120, Trp 33, and Val 153 (National Research Council, 1978). 
were immediately analysed for serum total cholesterol, HDL-cholesterol and triacylglycerols. The animal feeding and treatment protocol was reviewed and approved by the Animal Care Committee of Health Canada.

\section{Analytical methods}

Total $\mathrm{N}$ in the diets was determined by the micro-Kjeldahl method using a Kjeltec Auto 1030 analyser (Tecator, Herndon, VA, USA). Protein was calculated by using a N-toprotein factor of $6 \cdot 25$. Casein and gelatin were hydrolysed for $22 \mathrm{~h}$ with $6 \mathrm{M}-\mathrm{HCl}$ (Sarwar \& Peace, 1986) for determination of all amino acids except tryptophan and sulfur amino acids. The $4.2 \mathrm{M}-\mathrm{NaOH}$ hydrolysis was used for the quantitative measurement of tryptophan (Hugli \& Moore, 1972). Hydrolysates for the determination of sulfur amino acids (methionine as methionine sulfone and cystine/cysteine as cysteic acid) were prepared by performic acid oxidation of the protein followed by the $6 \mathrm{M}-\mathrm{HCl}$ hydrolysis (Moore, 1963). Amino acids in the acid hydrolysates were determined by liquid chromatography of precolumn phenylisothiocyanate derivatives (Sarwar et al. 1988). Tryptophan in the basic hydrolysate was determined by a simple liquid chromatographic method requiring no derivatization (Sarwar et al. 1988).

Total lipids were extracted from liver with chloroform-methanol $(2: 1, \mathrm{v} / \mathrm{v})$ (Bligh \& Dyer, 1959). Phospholipids (PL) were isolated by TLC with development in hexanediethyl ether-acetic acid $\left(80: 20: 1\right.$, by vol) and transmethylated with $\mathrm{BF}_{3}$-methanol. The fatty acid methyl esters were analysed by GLC using an SP-2560 flexible fused silica capillary column $(100 \mathrm{~m} \times 0.25 \mathrm{~mm}$ i.d.; Supelco, Inc., Bellefonte, PA, USA) in a HewlettPackard 5890 Series II gas chromatograph (Palo Alto, CA, USA). The fatty acids were identified by comparing their retention times with those of a standard mixture of fatty acids (GLC 68, NU Check Prep, Elysian, MN, USA). The fatty acids were expressed as g/100 g total fatty acids.

The blood was centrifuged at $1300 \mathrm{~g}$ for $20 \mathrm{~min}$ at $4^{\circ}$ and the serum separated. Serum total cholesterol, HDL-cholesterol and triacylglycerols were determined enzymically using the Boehringer Mannheim cholesterol C-system (Boehringer Mannheim GmbH Diagnostica, Mannheim, Germany).

\section{Statistical analysis}

All data are reported as means and standard deviations. For each response variable, an ANOVA was done using the Statistical Systems for Personal Computers (SAS Institute, Cary, NC, USA). The factors of interest were two types of protein (casein and gelatin), two levels of protein $(50$ and $300 \mathrm{~g} / \mathrm{kg}$ ), two levels of fat $(50$ and $150 \mathrm{~g} / \mathrm{kg})$ and two time points $(30 \mathrm{~d}$ and $120 \mathrm{~d})$ at which data were collected. Linear contrasts were constructed to examine both the main and interaction effects (Steel \& Torrie, 1980). The residuals from the model were examined for a lack of homogeneity and for outliers. Differences were considered significant when $P<0.05$.

\section{RESULTS}

Body weights

There were no differences $(P>0.05)$ observed in the weights of rats between the eight groups at the beginning of the experiment (434 (SD 18)-456 (SD 20) g) or after $30 \mathrm{~d}$ of 
Table 3. Effects of feeding casein or gelatin diets on serum triacylglycerol, total cholesterol and $H D L$-cholesterol levels ( $\mathrm{mmol} / \mathrm{l}$ ) in rats

(Mean values and standard deviations for five animals per group)

\begin{tabular}{|c|c|c|c|c|c|c|c|c|c|c|c|c|}
\hline \multirow[b]{3}{*}{ Diet } & \multicolumn{4}{|c|}{ Triacylglycerols } & \multicolumn{4}{|c|}{ Total cholesterol } & \multicolumn{4}{|c|}{ HDL-cholesterol } \\
\hline & \multicolumn{2}{|c|}{$30 \mathrm{~d}$} & \multicolumn{2}{|c|}{$120 \mathrm{~d}$} & \multicolumn{2}{|c|}{$30 \mathrm{~d}$} & \multicolumn{2}{|c|}{$120 \mathrm{~d}$} & \multicolumn{2}{|c|}{$30 \mathrm{~d}$} & \multicolumn{2}{|c|}{$120 \mathrm{~d}$} \\
\hline & Mean & SD & Mean & SD & Mean & SD & Mean & $S D$ & Mean & SD & Mean & SD \\
\hline HCLF & $3.44^{\mathrm{a}}$ & 0.87 & $7.05^{\mathrm{a}}$ & 1.56 & $3 \cdot 34^{\mathrm{a}}$ & 0.47 & $4.99^{\mathrm{a}}$ & 0.73 & $1.82^{\mathrm{a}}$ & 0.26 & $2.62^{\mathrm{a}}$ & 0.53 \\
\hline HCHF & $2 \cdot 24^{b}$ & 0.33 & $5 \cdot 76^{\mathrm{a}}$ & 1.65 & $2.90^{\mathrm{ab}}$ & 0.29 & $4.00^{b}$ & 0.26 & $1.76^{\mathrm{ab}}$ & 0.19 & $2 \cdot 22^{\mathrm{a}}$ & $0 \cdot 18$ \\
\hline LCLF & $3 \cdot 32^{a}$ & 0.56 & $3.99^{\mathrm{b}}$ & 0.67 & $2 \cdot 64^{\mathrm{bc}}$ & 0.25 & $2 \cdot 89^{\mathrm{c}}$ & 0.17 & $1.27^{\mathrm{ed}}$ & 0.11 & $1.41^{\mathrm{b}}$ & $0 \cdot 10$ \\
\hline $\mathrm{LCHF}$ & $1.67^{b}$ & 0.20 & $3 \cdot 46^{\mathrm{b}}$ & 0.40 & $2 \cdot 40^{\mathrm{bc}}$ & 0.16 & $2.73^{\mathrm{cd}}$ & 0.10 & $1 \cdot 31^{\mathrm{cd}}$ & 0.15 & $1.39^{\mathrm{b}}$ & 0.17 \\
\hline HGLF & $1 \cdot 32^{b}$ & 0.21 & $2.25^{\mathrm{bc}}$ & 0.21 & $2 \cdot 27^{\mathrm{c}}$ & $0 \cdot 11$ & $2.99^{c}$ & 0.08 & $1 \cdot 15^{\mathrm{d}}$ & $0 \cdot 10$ & $1.67^{\mathrm{b}}$ & 0.14 \\
\hline HGHF & $1.41^{\mathrm{b}}$ & 0.24 & $1.67^{\mathrm{c}}$ & 0.59 & $2 \cdot 29^{\mathrm{c}}$ & 0.21 & $2 \cdot 20^{\mathrm{d}}$ & 0.35 & $1.41^{\mathrm{cd}}$ & 0.19 & $1.42^{\mathrm{b}}$ & 0.15 \\
\hline LGLF & $2 \cdot 14^{b}$ & 0.62 & $2.71^{b c}$ & 0.35 & $2.72^{\mathrm{bc}}$ & 0.20 & $2.99^{c}$ & 0.10 & $1.44^{\text {bed }}$ & 0.13 & $1.72^{b}$ & 0.09 \\
\hline LGHF & $1.72^{b}$ & $0-62$ & $3 \cdot 17^{\text {bc }}$ & 0.39 & $2.49^{\mathrm{bc}}$ & 0.15 & $2.73^{\mathrm{cd}}$ & 0.16 & $1.55^{\mathrm{abc}}$ & 0.15 & $1.60^{b}$ & 0.13 \\
\hline
\end{tabular}

H, high; L, low; C, casein; G, gelatin; F, fat.

${ }_{a, b, c, d}$ Mean values within a column not sharing a common superscript letter were significantly different, $P<0 \cdot 05$.

feeding (438 (SD 34)-469 (SD 20) g). Similarly, the differences in the weights of rats fed on various diets for $120 \mathrm{~d}$ of feeding were small (about $10 \%, 467$ (SD 33)-518 (SD 17) g).

\section{Serum triacylglycerols, total cholesterol and HDL-cholesterol}

The serum lipid composition is shown in Table 3. On average, the eight casein groups (HCLF, HCHF, LCLF and LCHF, 30 and 120d) had higher levels $(P<0.05)$ of serum triacylglycerols $(3.87(\mathrm{SD} \mathrm{0.78)} v .1 .95(\mathrm{SD} \mathrm{0.40)} \mathrm{mmol} / \mathrm{l})$, total cholesterol $(3.23(\mathrm{SD} 0.31)$ v. 2.58 (SD 0.17) mmol/l) and HDL-cholesterol (1.72 (SD 0.21) v. 1.49 (SD 0.13) mmol/l) than the eight gelatin groups (HGLF, HGHF, LGLF and LGHF, 30 and $120 \mathrm{~d}$ ).

The high-casein groups (HCLF and HCHF) had higher average levels $(P<0.05)$ of serum triacylglycerols $(4.62(\mathrm{SD} 1.10) v .3 .11(\mathrm{SD} \mathrm{0.46)} \mathrm{mmol} / \mathrm{l})$, total cholesterol (3.81 (SD $0.42)$ v. 2.66 (SD 0.15) mmol/l) and HDL-cholesterol (2.10 (SD 0.29) v. 1.34 (SD $0.13) \mathrm{mmol} / \mathrm{l}$ ) compared with the low-casein groups (LCLF and LCHF). The opposite was, however, true in the case of gelatin where the low-gelatin groups (LGLF and LGHF) had higher levels $(P<0.05)$ of the three serum variables compared with the high-gelatin groups (HGLF and HGHF) (2.43 (SD 0.50) v. 1.66 (SD 0.30); 2.73 (SD 0.15) v. 2.44 (SD $0.20) ; 1.58$ (SD 0.13) v. 1.39 (SD 0.15 ) mmol/1 respectively).

The average serum triacylglycerol, total cholesterol and HDL-cholesterol levels of all the dietary groups were higher $(P<0.05)$ at $120 \mathrm{~d}$ than at $30 \mathrm{~d}(3.76(\mathrm{SD} 0.73) v .2 .16$ (SD 0.46 ); 3.10 (SD 0.25) v. 2.63 (SD 0.23); 1.76 (SD 0.19) v. 1.47 (SD 0.16) $\mathrm{mmol} / 1$ respectively). At both $30 \mathrm{~d}$ and $120 \mathrm{~d}$, the HCLF group had higher $(P<0.05)$ concentrations of serum triacylglycerols, total cholesterol and HDL-cholesterol than all other dietary groups except the triacylglycerol value at $30 \mathrm{~d}$ for LCLF, the triacylglycerol value at $120 \mathrm{~d}$ for $\mathrm{HCHF}$, total cholesterol value at $30 \mathrm{~d}$ for $\mathrm{HCHF}$, and $\mathrm{HDL}$-cholesterol value at $30 \mathrm{~d}$ or $120 \mathrm{~d}$ for HCHF (Table 3 ).

\section{Fatty acid composition of liver phospholipids}

The levels of the nutritionally important PUFA, linoleic acid $(18: 2 n-6)$, AA $(20: 4 n-6)$ and DHA $(22: 6 n-3)$ are shown in Table 4 . Time of study had significant $(P<0.05)$ effects on 
Table 4. Effect of feeding casein or gelatin diets on linoleic, arachidonic (AA) and docosahexaenoic acid (DHA) levels ( $\mathrm{g} / 100 \mathrm{~g}$ total fatty acids) in liver phospholipids of rats

(Mean values and standard deviations for five animals per group)

\begin{tabular}{|c|c|c|c|c|c|c|c|c|c|c|c|c|}
\hline \multirow[b]{3}{*}{ Diet } & \multicolumn{4}{|c|}{$18: 2 n-6$} & \multicolumn{4}{|c|}{ AA } & \multicolumn{4}{|c|}{ DHA } \\
\hline & \multicolumn{2}{|c|}{$30 \mathrm{~d}$} & \multicolumn{2}{|c|}{$120 \mathrm{~d}$} & \multicolumn{2}{|c|}{$30 \mathrm{~d}$} & \multicolumn{2}{|c|}{$120 \mathrm{~d}$} & \multicolumn{2}{|c|}{$30 \mathrm{~d}$} & \multicolumn{2}{|c|}{$120 \mathrm{~d}$} \\
\hline & Mean & SD & Mean & $\mathrm{SD}$ & Mean & $\mathrm{SD}$ & Mean & $\mathrm{SD}$ & Mean & $\mathrm{SD}$ & Mean & SD \\
\hline HCLF & $10 \cdot 4^{\mathrm{a}}$ & 1.7 & $7.4^{\mathrm{de}}$ & 1.2 & $23 \cdot 3^{\mathrm{ab}}$ & 3.9 & $27 \cdot 6^{\mathrm{ab}}$ & 2.7 & $7.8^{\mathrm{ab}}$ & 1.9 & $10 \cdot 2^{\mathrm{abc}}$ & $2 \cdot 0$ \\
\hline $\mathrm{HCHF}$ & $10 \cdot 9^{a}$ & 1.9 & $7 \cdot 0^{\mathrm{e}}$ & 0.6 & $26 \cdot 7^{\mathrm{a}}$ & $4 \cdot 6$ & $31 \cdot 2^{\mathrm{a}}$ & 1.4 & $10 \cdot 3^{\mathrm{ab}}$ & $2 \cdot 2$ & $12 \cdot 4^{\mathrm{a}}$ & 1.5 \\
\hline LCLF & $12 \cdot 6^{a}$ & 0.2 & $9 \cdot 3^{b}$ & 0.8 & $22 \cdot 3^{\mathrm{a}}$ & 2.4 & $23 \cdot 9^{\mathrm{b}}$ & $2 \cdot 8$ & $8 \cdot 2^{\mathrm{ab}}$ & $1 \cdot 1$ & $8 \cdot 2^{\mathrm{cd}}$ & 1.3 \\
\hline LCHF & $13 \cdot 9^{\mathrm{a}}$ & 0.9 & $10 \cdot 9^{\mathrm{a}}$ & 0.9 & $21 \cdot 7^{\mathrm{ab}}$ & $1 \cdot 2$ & $28 \cdot 0^{\mathrm{ab}}$ & 1.2 & $8 \cdot 2^{a b}$ & 0.7 & $9 \cdot 1^{\text {bcd }}$ & 0.7 \\
\hline HGLF & $13 \cdot 0^{\mathbf{a}}$ & 1.3 & $8 \cdot 5^{\mathrm{cd}}$ & 0.9 & $22 \cdot 9^{\mathrm{ab}}$ & 2.7 & $28 \cdot 1^{\mathrm{ab}}$ & 2.6 & $9 \cdot 6^{\mathrm{ab}}$ & $1 \cdot 1$ & $10 \cdot 3^{\mathrm{ab}}$ & 0.7 \\
\hline HGHF & $14 \cdot 6^{\mathrm{a}}$ & 0.6 & $11 \cdot 5^{\mathrm{a}}$ & 0.8 & $21 \cdot 0^{\mathrm{ab}}$ & 0.4 & $27.9^{\mathrm{ab}}$ & 1.6 & $7 \cdot 2^{\mathrm{ab}}$ & 0.9 & $9.9^{b c}$ & 0.7 \\
\hline LGLF & $13 \cdot 3^{\mathrm{a}}$ & 1.0 & $9.8^{\mathrm{bc}}$ & 0.6 & $20.9^{\mathrm{ab}}$ & $2 \cdot 6$ & $27 \cdot 4^{\mathrm{ab}}$ & 1.4 & $7 \cdot 6^{\mathrm{ab}}$ & $2 \cdot 1$ & $9 \cdot 7^{b c}$ & 0.7 \\
\hline LGHF & $13 \cdot 5^{a}$ & 0.7 & $10 \cdot 7^{\mathrm{ab}}$ & $1 \cdot 1$ & $20 \cdot 3^{\mathrm{b}}$ & 3.9 & $25 \cdot 9^{\mathrm{ab}}$ & $1 \cdot 3$ & $6.8^{b}$ & 2.0 & $7 \cdot 3^{d}$ & 1.4 \\
\hline
\end{tabular}

$H$, high; L, low; C, casein; G, gelatin; F, fat.

a,b,c,d,e Mean values within a column not sharing a common superscript letter were significantly different, $P<0.05$.

the concentration of all three PUFA. The average concentrations of AA (the most important metabolite of $18: 2 n-6$ ) and DHA (the most important metabolite of $\alpha$-linolenic acid) for all the dietary groups were higher at $120 \mathrm{~d}$ than at $30 \mathrm{~d}$ (27.5 (SD 1.9), 9.6 (SD 1.0) v. 22.4 (SD $2.7)$ and $8.2(\mathrm{SD} 1.5) \mathrm{g} / 100 \mathrm{~g}$ total fatty acids respectively) but the average concentration of $18: 2 n-6$ was lower at $120 \mathrm{~d}$ than at $30 \mathrm{~d}(9.4$ (SD 0.9) v. $12.7($ SD 1.0$) \mathrm{g} / 100 \mathrm{~g}$ total fatty acids). The level of $\alpha$-linolenic acid (not shown in Table 4), the precursor of long-chain $n-3$ PUFA, in liver PL was low (0.1-0.3 g/100 g total fatty acids), and was unaffected by diet or age.

The level of fat in the diet also significantly influenced the concentration of $18: 2 n-6$ in the liver, the average concentration being higher $(P<0.05)$ at high levels of fat (HCHF, LCHF, HGHF and LGHF) than at low levels of fat (LCLF, HCLF, LGLF and HGLF) (11.6 (SD 0.9) v. 10.5 (SD 1.0) g/100 g total fatty acids). Protein source $\times$ protein levels also had a significant effect on the concentrations of $18: 2 n-6$ and AA. The high-casein groups (HCLF and HCHF) had higher $(P<0.05)$ average concentrations of AA but lower concentrations of $18: 2 n-6$ than the low-casein groups (LCLF and LCHF) (27.2 (SD 3.0), 8.9 (SD 1.3) v. 24.0 (SD 1.9) and 11.7 (SD 0.7) g/100 g total fatty acids respectively).

\section{DISCUSSION}

All the experimental diets met or exceeded the indispensable amino acid requirements for rat maintenance as specified by the National Research Council (1978). Although the requirements are based on a diet containing $48 \mathrm{~g}$ protein $/ \mathrm{kg}$ from casein and $50 \mathrm{~g}$ fat $/ \mathrm{kg}$, extrapolation of the requirement to $300 \mathrm{~g}$ protein $/ \mathrm{kg}$ and $150 \mathrm{~g}$ fat $/ \mathrm{kg}$ diets was assumed to be safe because a constant amino acid: energy ratio was maintained (National Research Council, 1978). The fact that there were no significant differences in body weights of rats fed on different diets for $30 \mathrm{~d}$ would confirm the nutritional adequacy of the diets for rat maintenance. Similarly, the differences in body weights of rats fed on various experimental diets for $120 \mathrm{~d}$ were small.

In the present study, the average levels of serum triacylglycerols, cholesterol and HDL-cholesterol were significantly lower in rats fed on the gelatin diets compared with those fed on the casein diets. The hypocholesterolaemic effect of gelatin (an animal 
protein) observed in the present study has not been reported previously. After $120 \mathrm{~d}$ of testing, the levels of serum triacylglycerols and cholesterol in rats fed on the HGHF diet were less than one third and half of the levels in rats fed on the HCHF diet respectively. Gelatin is an incomplete protein and the present study is not advocating the consumption of unsupplemented gelatin for human nutrition. The marked hypocholesterolaemic effect of the HGHF diet (gelatin protein supplemented with small amounts of isoleucine, methionine and tryptophan) noted in this study should, however, be investigated in human subjects to evaluate its potential pharmacological effect in lowering serum cholesterol levels. Treatment with pravastatin was reported to lower plasma cholesterol levels by $20 \%$ and LDL-cholesterol by $26 \%$ in men with hypercholesterolaemia (Shepherd et al. 1995).

A comparison of the amino acid compositions of casein and gelatin (both animal proteins) studied in this investigation revealed that casein contained higher levels of glutamic acid, methionine, phenylalanine and tyrosine (cholesterol-raising amino acids) than gelatin, while gelatin contained a higher level of arginine (cholesterol-lowering amino acid) than casein. This would lend support to the suggestion that the differences in amino acid composition of proteins (regardless of their source, animal or plant) may be partly responsible for the alterations of plasma cholesterol level in rats fed on different animal and plant proteins (Sautier et al. 1983, 1986; Jacques et al. 1986; Sugiyama \& Muramatsu, 1990). Gelatin also contained about twelve times more glycine than casein. Apart from its contribution to protein synthesis, glycine is required in disproportionately large amounts for the formation of haem, creatine, collagen, nucleic acids and bile salts (Jackson, 1991). The requirement for the endogenous synthesis of glycine was reported to be between ten and fifty times the dietary intake (Neuberger, 1981). Therefore, it is possible that the extremely high level of glycine in gelatin may be partly responsible for its hypocholesterolaemic activity. Further experiments involving amino acid supplementation of casein and gelatin are required to prove conclusively that the widely different cholesterolaemic responses of the two animal protein sources noted in the present study are due to differences in their amino acid profiles.

The present study also shows that the elevation of the serum lipids (triacylglycerols, total cholesterol and HDL-cholesterol) is accompanied by changes in the liver PL fatty acid profile. Feeding of the HCHF diet to rats resulted in reduced levels of $18: 2 n-6$ but increased levels of AA and DHA in liver phospholipids. This increase in the $n-6$ and $n-3$ metabolites of $18: 2 n-6$ and $\alpha$-linoleic acid might indicate an increase in $\Delta 6$ desaturase activity. Similar observations about the influence of a high-casein diet on the metabolism of 18:2n-6 have been made previously (Koba \& Sugano, 1990; Koba et al. 1990, 1991, 1993).

Koba \& Sugano (1990) showed that casein $(200 \mathrm{~g} / \mathrm{kg}$ diet) promoted desaturation of $18: 2 n-6$ in rat liver phosphatidylcholine (PC) compared with soyabean protein isolate $(200 \mathrm{~g} / \mathrm{kg}$ diet). The effect of protein sources was detected within $4 \mathrm{~d}$ after feeding different proteins and persisted even after an overnight fast. The addition of arginine to the casein diet tended to increase linoleic acid and to decrease AA in rat liver PC, while the effect of lysine addition was inconclusive. The magnitude of linoleic desaturation $(18: 3 n$ $6+20: 3 n-6+20: 4 n-6) / 18: 2 n-6)$ was similar in rats fed on casein or potato protein but was significantly lower in rats fed on soyabean protein (Koba \& Sugano, 1990). Soyabean protein contained twice as much arginine as casein or potato protein, while the lysine : arginine ratios for casein, potato protein and soyabean protein were $2.1,1.5$ and 0.9 respectively, suggesting that the arginine content rather than the lysine: arginine ratio was at least one of the factors for the protein-dependent regulation of linoleic acid metabolism (Koba \& Sugano, 1990). In the present investigation, the lowest levels of AA and DHA 
were found in rats fed on the LGHF diet while highest levels of AA and DHA were found in rats fed on the HCHF diet. Since gelatin contained twice the level of arginine than casein, it is possible that arginine may have some influence on the metabolism of essential fatty acids.

In the present study, the HCHF diet not only increased the concentration of serum cholesterol but also increased the liver PL levels of AA and DHA compared with the gelatin diets. This observation is in general agreement with the data of Koba et al. (1993) who observed in rats that dietary protein modulates microsomal cholesterol levels, cholesterol : phospholipid ratio and membrane fluidity, and subsequently the activity of $\Delta 6$ desaturase in rat liver microsomes. Based on the present study and on the observations of Koba et al. (1993), it is suggested that a protein source which increases serum cholesterol may also promote the biosynthesis of essential fatty acids, AA and DHA.

The authors thank Laurent Samure, Kevin Kittle and Dominique Patry for the care of the animals. The technical assistance of G. Pelletier, H. G. Botting and J. Matte is greatly appreciated.

\section{REFERENCES}

American Institute of Nutrition (1977). Report of the American Institute of Nutrition ad hoc committee on standards for nutritional studies. Journal of Nutrition 107, 1340-1348.

American Institute of Nutrition (1980). Second report of the ad hoc committee on standards for nutritional studies. Journal of Nutrition 110, 1726.

Bligh, E. G. \& Dyer, W. G. (1959). A rapid method of total lipid extraction and purification. Canadian Journal of Biochemistry and Physiology 37, 911-917.

Brenner, R. R. (1981). Nutritional and hormonal factors influencing desaturation of essential fatty acids. Progress in Lipid Research 20, 41-47.

Carroll, K. K. (1991). Review of clinical studies on cholesterol lowering response to soy protein. Journal of the American Dietetic Association 91, 820-827.

Carroll, K. K. \& Kurowska, E. M. (1995). Soy consumption and cholesterol reduction: review of animal and human studies. Journal of Nutrition 125, 594S-597S.

Erdman, J. W. Jr \& Fordyce, E. (1989). Soy products and the human diet. American Joumal of Clinical Nutrition 49, 725-737.

Hugli, T. E. \& Moore, S. (1972). Determination of tryptophan content of alkaline hydrolysates. Journal of Biological Chemistry 267, 2828-2834.

Inkpen, C. A., Harris, R. R. \& Quackenbush, F. Q. (1969). Differential responses to fasting and subsequent feeding by microsomal systems of rat liver: $\Delta 6$ - and $\Delta 9$-desaturation of fatty acids. Journal of Lipid Research 10, 277-282.

Jackson, A. A. (1991). The glycine story. European Journal of Clinical Nutrition 45, 59-65.

Jacques, H., Deshaies, Y. \& Savoie, L. (1986). Relationship between dietary proteins, their in vitro digestion products, and serum cholesterol in rats. Atherosclerosis 16, 89-98.

Koba, K., Abe, K. \& Sugano, M. (1990). Effect of amino acid composition of dietary protein on linoleic acid desaturation in rats. Agricultural and Biological Chemistry 54, 2711-2717.

Koba, K., Abe, K., Wakamatsu, K. \& Sugano, M. (1991). Effect of overnight fasting on the fatty acid composition of tissue lipids in rats fed with different proteins. Agricultural and Biological Chemistry 55, 1363-1373.

Koba, K. \& Sugano, M. (1990). Dietary protein infuences polyunsaturated fatty acid patterns of rat tissue lipids. Joumal of Nutritional Science and Vitaminology 36, 173S-176S.

Koba, K., Wakamatsu, K., Obata, K. \& Sugano, M. (1993). Effects of dietary proteins on linoleic acid desaturation and membrane fluidity in rat liver microsomes. Lipids 28, 457-464.

Kritchevsky, D. (1995). Dietary protein, cholesterol and atherosclerosis: a review of the early history. Journal of Nutrition 125, 589S-593S.

Moore, S. (1963). On the determination of cystine as cysteic acid. Journal of Biological Chemistry 238, 235237.

National Research Council (1978). Nutrient Requirements of Laboratory Animals, 3rd revised ed., pp. 7-37. Washington, DC: National Academy of Sciences.

Neuberger, A. (1981). The metabolism of glycine and serine. Comparative Biochemistry 19A, 257-303. 
Peluffo, R. O., de Gomez Dumm, N. T., de Alaniz, M. J. T. \& Brenner, R. R. (1971). Effect of protein and insulin on linoleic acid desaturation of normal and diabetic rats. Journal of Nutrition 101, 1075-1084.

Peluffo, R. O., Nervi, A. B., Gonzalez, M. S. \& Brenner, R. R. (1984). Effect of different amino acid diets on $\Delta 5$, $\Delta 6$ and $\Delta 9$ desaturases. Lipids 19, $154-157$.

Sarwar, G., Botting, H. G. \& Peace, R. W. (1988). Complete amino acid analysis in hydrolysates of foods and faeces by liquid chromatography of precolumn phenylisothiocyanate derivatives. Joumal of the Association of Official Analytical Chemists 71, 1172-1175.

Sarwar, G. \& Peace, R. W. (1986). Comparison between true digestibility of total nitrogen and limiting amino acids in vegetable protein fed to rats. Journal of Nutrition 116, 1172-1184.

Sautier, C., Dieng, K., Flament, C., Doucet, C., Suquet, J. P. \& Lemonnier, D. (1983). Effect of whey protein, casein, soyabean, and sunflower proteins on the serum, tissue and faecal steroids in rats. British Journal of Nutrition 49, 313-319.

Sautier, C., Flamant, C., Doucet, C. \& Suquet, J. P. (1986). Effects of eight dietary proteins and their amino acid content on serum, hepatic and faecal steroids in the rat. Nutrition Reports International 34, 1051-1061.

Shepherd, J., Cobbe, S. M., Ford, I., Isles, C. G., Lorimer, A. R., MacFarlane, P. W., McKillop, J. H. \& Packard, C. J. (1995). Prevention of coronary heart disease with pravastatin in men with hypercholesterolaemia. New England Journal of Medicine 333, 1301-1307.

Steel, R. G. D. \& Torrie, J. H. (1980). Principles and Procedures of Statistics: A Biometrical Approach, $2 \mathrm{nd}$ ed. Toronto: McGraw-Hill Book Company.

Sugiyama, K. \& Muramatsu, K. (1990). Significance of the amino acid composition of dietary protein in the regulation of plasma cholesterol. Journal of Nutritional Science and Vitaminology 36, 105S-110S. 